\title{
Id-1 expression in colorectal adenocarcinoma tissues and its clinical significance
}

\author{
Xue-Liang Wu ${ }^{1, *}$ \\ iD) Yuan-Yuan Wang,,* \\ (iD) Li-Kun Wang ${ }^{2}$ \\ (iD) Jun Xue \\ Dong-Dong Yang ${ }^{1}$ \\ (iD) Ming Qu ${ }^{1}$ \\ iDChen-Yu Wang \\ (iD) Fei Guo ${ }^{1}$ \\ (iD) Rui-Min Yang ${ }^{2}$ \\ (iD) Bo Liu $^{3}$
}

\begin{abstract}
* Xue-Liang Wu and Yuan-Yuan Wang have contributed equally to this study 1. Department of General Surgery, First Affiliated Hospital of Hebei North University, Zhangjiakou 075000, China 2. Department of Ultrasound First Affiliated Hospital of Hebei North University, Zhangjiakou 075000, China 3. Department of Pathology First Affiliated Hospital of Hebei North University, Zhangjiakou 075000 , China 4. Department of Gastrointestinal Surgery, The First Hospital of Hebei Medical University, Shijiazhuang, 050031, China
\end{abstract}

http://dx.doi.org/10.1590/1806-9282.65.3.404

\section{SUMMARY}

BACKGROUND: This study aims to investigate the expression of Id-1 in human colorectal adenocarcinoma tissues and explore its correlation with the clinical pathological parameters of colorectal cancer.

METHODS: The Id-1 mRNA and protein expression levels of 50 specimens of normal colorectal tissues and 50 specimens of colorectal adenocarcinoma tissues were detected using reverse-transcription polymerase chain reaction and western blot. Furthermore, Id-1 protein was detected using immunohistochemistry. The correlation between the expression of Id-1 and clinicopathologic features was analyzed. RESULTS: The mRNA expression level of Id-1 in colorectal adenocarcinoma tissues and normal colorectal tissues was $0.96 \pm 0.03$ vs. $0.20 \pm 0.04$, respectively; and the difference was statistically significant $(P=0.011)$. Furthermore, Id-1 protein expression was higher in colorectal adenocarcinoma tissues than in normal colorectal tissues ( $0.82 \pm 0.04$ vs. $0.31 \pm 0.02, P=0.020$ ). In addition, the positive protein expression rate of Id- 1 was higher in colorectal adenocarcinoma tissues than in normal colorectal tissues (72.00\% vs. 24.00\%, $X 2=23.437, P=0.000)$. The expression of Id-1 was correlated with the depth of tumor invasion, TNM stage, lymph node metastasis, vessel invasion, and liver metastasis $(P<0.01)$. However, this expression was not correlated with tumor size and differentiation degrees $(P>0.05)$.

CONCLUSIONS: The high Id-1 expression in colorectal adenocarcinoma tissues play an important role in the process of cancer, and is expected to become a new tumor monitoring indicator for clinical diagnosis, treatment, and prognosis judgment.

KEYWORDS: Colorectal neoplasms. Immunohistochemistry. Blotting, Western. Adenocarcinoma.

\section{INTRODUTION}

Inhibitors of DNA binding-1 (Id-1) have been an enthusiastically studied oncogene that can promote cell proliferation, induce tumor angiogenesis, enhance tumor growth invasion, and accelerate tu- mor growth and metastasis through animal experiments ${ }^{1,2}$. To date, it has been proven that Id-1 takes on a high expression state in multiple malignant tumors such as breast cancer, cervical cancer, and

DATE OF SUBMISSION: 23-Jul-2018

DATE OF ACCEPTANCE: 27-Aug-2018

CORRESPONDING AUTHOR: Jun Xue

Department of General Surgery, First Affiliated Hospital of Hebei North University

No.12 of Changqing Street, Qiaoxi District, Zhangjiakou 075000 - China - Tel: +15530396660 - Fax: +03138022373

Email:xuejun_cn@126.com 
esophagus cancer ${ }^{3-5}$. However, studies in the field of colorectal cancer have been relatively few. This study aimed at investigating the expression of Id-1 in colorectal cancer and its relationship with related clinicopathological factors through immunohistochemistry, RT-PCR, and western blot analysis.

\section{METHODS}

\section{Cases data}

Fifty cases of colorectal cancer tissues excised during general surgery and 50 cases of normal tissues were collected between May 2012 and May 2014 from the First Affiliated Hospital of Hebei North University. Cancerous tissues were selected from the Cancer Lesions Center. In addition, incisal edges of specimen stub ends were selected, which were confirmed to be normal colorectal tissues by pathology. All cases had primary tumors, and targeted treatments such as neoadjuvant chemoradiotherapy were not performed prior to the operation. The male-to-female proportion of these subjects was 29:21, and their age ranged was 33-71 years, with an average age of $51.2 \pm 2.9$ years. Furthermore, among cases with normal colorectal tissues, the male-tofemale proportion was $28: 22$, and their age ranged from 33-69 years, with an average age of $52.0 \pm 2.1$ years. The general data of cases in these two groups were comparable $(P>0.05)$.

\section{Main Reagents and Experimental Methods \\ Main Reagents}

Rabbit anti-human monoclonal concentrated Id-1 antibody (ab50932 R2-1G6) was purchased from Abcam(Hong Kong); rabbit anti-human GAPDH polyclonal primary antibody (ab54621R2-3) and goat anti-rabbit secondary antibody (ab5214R2-2) were purchased from Santa Cruz Biotechnology (USA); Total RNA extraction reagent, reverse transcription kit, SDS-PAGE standard indicator, and BCA protein quantification kit were all purchased from Fermentas (Thermo Scientific, USA); RIPA reagents were purchased from Solarbio (Beijing, China); DAB color developing agent was purchased from Tiangen Biotech (Beijing, China). The primer was synthesized by Takara Bio .

Id-1 mRNA expression was detected by RT-PCR assay.

The total RNA concentration was extracted and determined. Id-1 upstream primer was 5'-CTGAG-GCACTGGCGAGGAGA-3' and Id-1 down- stream primer was 5'-GAGAAGCACCAAACGTGACCAT-3'; and the length was amplified by 140 bp. GAPDH ( $\beta$-actin): upstream primer was 5'-ACCCACTCCTC-CACCTTGA-3' and downstream primer was 5'-ACCACCCTGTT-GCTGTAGCC-3'; and the length was amplified by 107 bp. Reaction system: $2.5 \mathrm{ml}$ of $1 \times$ PCR Buffer, $0.5 \mathrm{ml}$ of dNTP, $2 \mathrm{ml}$ of cDNA template, $1.25 \mathrm{U}$ of Tag enzyme, $1 \mathrm{ml}$ of each upstream and downstream primer, $1 \mathrm{ml}$ of RNA enzyme inhibitor, and $25 \mathrm{ml}$ of total reaction volume. The amplification was operated according to kit specifications: $1 \mathrm{ml}$ of DNA sample was taken as the template, and deionized water was taken as the negative control template. The amplification was carried out under the following conditions: $95^{\circ} \mathrm{C}$ for two minutes pre-degeneration; at $95^{\circ} \mathrm{C}$, for 10 seconds, at annealing temperature, for 15 seconds; at $72^{\circ} \mathrm{C}$, extended to 45 seconds, with a total of 35 circulations; finally, at $72^{\circ} \mathrm{C}$, extended again for 10 minutes. After adding $2 \%$ of sepharose gel, the product was electrophoretically separated; the result was observed under an ultraviolet radiator.

Id-1 protein expression was detected by western blot assay.

Total protein was extracted by RIPA lysate and quantified. Then, $50 \mathrm{mg}$ of protein was taken, placed into a $5 \times$ buffer solution (4:1), water baths were performed three times for five minutes at $100^{\circ} \mathrm{C}$, followed by electrophoresis with $8 \%$ polyacrylamide gel (SDS-PAGE), and the specimen was shifted onto PVDF membranes. Next, the membrane was removed, 5\% skim milk powder was added for confining; the confining liquid was discarded. The specific primary antibody was added dropwise (Id-1: 1:1 500; GAPDH: 1:150) and incubated overnight at $4^{\circ} \mathrm{C}$. TBST washing liquid was added three times for 10 minutes. The specific secondary antibody was added $(1: 1,500)$ and incubated for one hour at $37^{\circ} \mathrm{C}$. TBST washing liquid was added three times again for 10 minutes. The stripes were detected by the ECL method, and quantitative analysis on density was conducted.

Protein expression was detected by immunohistochemical staining

Some specimens were fixed by $10 \%$ formaldehyde solution and embedded by paraffin wax, with a slice thickness of $4 \mathrm{~mm}$. Then, hematoxylin and eosin (H\&E) staining method were used for pathological diagnosis. The slices were roasted in an oven for 30 
minutes at $80^{\circ} \mathrm{C}$, then dehydrated using ethanol; endogenous peroxidase inactivated, hydrated repaired using citric acid buffer solution at high temperature and under high pressure, washed for three times by PBS. The primary antibody was added and cultured overnight at $4^{\circ} \mathrm{C}$, then washed three times with PBS. The secondary antibody was added. At room temperature, the specimens were color developed by DAB, counterstained with hematoxylin, and differentiated with $1 \%$ hcl-ethanol for five minutes. Then, the specimens were rinsed with running water for five minutes, dehydrated with gradient ethanol, transparentized with turpentine for five minutes, and eventually sealed with gum. In the negative control group, the primary antibody was replaced by PBS.

\section{Assessment of the positive expression of Id-1}

In the cytoplasm, particles stained in claybank and brown were positive cells. Positive cell percentage was calculated and scored as follows: $\leq 5 \%$ was scored 0; 6\%-25\% was scored $1 ; 26 \%-50 \%$ was scored 2 ; $51 \%-75 \%$ was scored 3 ; and $>75 \%$ was scored 4 . No color was scored 0 ; yellow was scored 1 ; and deep yellow was scored 3 . These two were multiplied, with 0 being (-), 1-4 being $(+)$, 5-8 being $(++)$, and 9-12 being $(+++)$; and $(+)-(+++)$ were all regarded as positive.

\section{Statistical method}

SPSS 17.0 statistical software was used for the analysis. Measurement data were indicated as $\mathrm{x} \pm$ SD. The t-test was used for comparison between the two groups. Measurement data was presented in percentage. The $X^{2}$-test was used to test and analyze the expression of Id-1 and its relationship with clinicopathological parameters. For the inspection level, $\alpha=0.05$ was assumed.

\section{RESULTS}

\section{RT-PCR test results for Id-1}

By taking the ratio of Id-1/GAPDH for the RT-PCR quantitative analysis, the mRNA expression level of Id-1 was significantly higher in cancerous tissues than in colorectal normal tissues; and the difference was statistically significant $(0.96 \pm 0.03$ vs. $0.20 \pm$ 0.04, $P=0.011$; as shown in Figure 1).

\section{Id-1 test results by western blot}

The ratio of Id-1/GAPDH was taken for the protein quantitative test. In addition, the protein expression level of Id-1 was higher in colorectal cancer tissues than in colorectal normal tissues; the difference was statistically significant $(0.82 \pm 0.04$ vs. $0.31 \pm 0.02$, $P=0.020$; as shown in Figure 2).

\section{Immunohistochemical test results for Id-1}

The positive expression rate in colorectal cancer tissues $(72.00 \%, 36 / 50)$ was significantly higher than in normal mucous membranes $(24.00 \%, 12 / 50)$, and the difference was statistically significant $\left(X^{2}=\right.$ 23.431, $P=0.000$; Figure 3).

The relationship between Id-1 protein and clinicopathological parameters

The protein expression level was not associated with the tumor size of patients and the differentiation degree but was closely related to tumor serosa infiltration, hepatic metastasis, lymphatic metastasis, tumor TNM stages, and vessel infiltration $(P<0.01)$.

\section{DISCUSSION}

Id-1 is an important member of the helix-loop-helix (HLH) transcription factor family and a negative regulatory factor of cell differentiation. It has been widely expressed in the embryos of mammals, reproduction glands, and some immaturely differentiated histocytes. In normal tissues, it has a state of micro-expression or no expression. However, it has high expression in many malignant tumors and in vitro cultivated tumor cells. It is also related to the malignant potential and prognosis of tumors ${ }^{6}$. Most HLH structures have one closed adjacent basic HLH (bHLH) factor. These two are mutually combined to form a heterodimer, then are combined with targeted DNA to induce the E-box-like-structure target gene in the promoter to transcribe and integrate the so-called "E-box" DNA sequence in order to regulate and control cell proliferation and differentiation ${ }^{7}$.

Id-1 enhances cell proliferation and invasion in multiple ways. Studies have confirmed that Id-1 forms a specific complex to inhibit E2A, activate P21, activate $\mathrm{CDK} 2$, induce $\mathrm{Rb}$ protein phosphorylation, inhibit G1/S stagnation during the cell division cycle and initiates the cell division cycle by combining with E2A ${ }^{8}$. The upregulation of Id- 1 can enhance TGF- $\beta 1$ expression, reduce E-calcium mucoprotein expression, and induce materialization between epithelial cells, which leads to loss of polarity between cells, as well as the reduction of adhesion. This would induce 
cancerous cells to break through the basilar membrane barrier, metastasize, and infiltrate to tissues in the vicinity ${ }^{9,10}$.

\section{CONCLUSIONS}

The results of this experiment revealed that the mRNA and protein expression of Id-1 was significantly higher in glandular cancer tissues than in normal tissues, which confirms that the specific high expression of Id-1 may play an important role in the process of occurrence and development of colorectal cancer. ${ }^{11}$ It also revealed that the expression of Id-1 in non-small cell lung cancer gradually increased with the deepening of tumor infiltration. Furthermore, this was enhanced with lymph node and distant metastasis, which had a higher expression in lung cancer tissues at TNM III and IV stages. ${ }^{12}$ Immunohistochemical assays were performed on 60 cases of esophageal squamous carcinoma tissues and revealed that the positive expression of Id- 1 was significantly higher in esophageal squamous carcinoma than in normal esophagus mucous membranes. ${ }^{13}$ The positive expression of Id-1 in the normal gastric

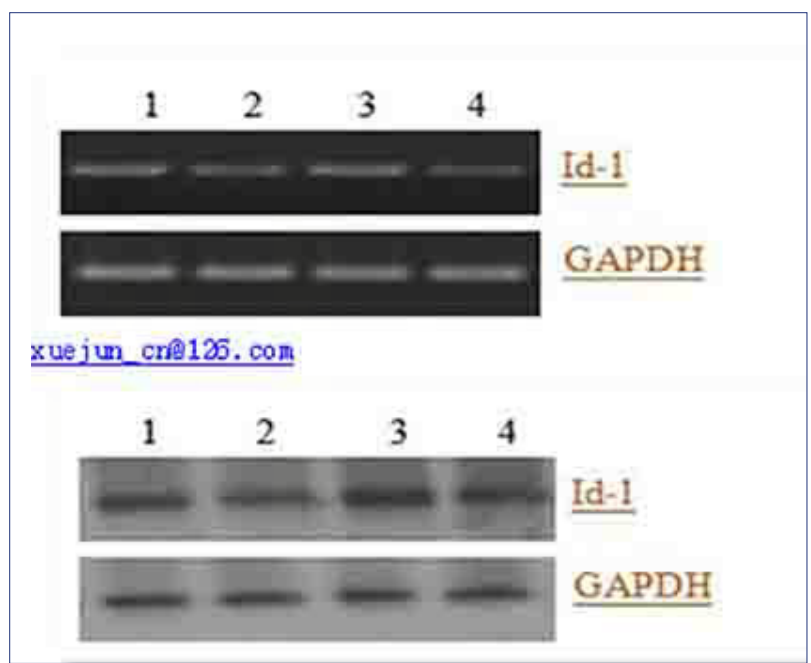

FIGURE 1. Expression level of Id-1 mRNA in colorectal adenocarcinoma and normal colorectal tissues detected by reverse-transcription polymerase chain reaction.

1-3 colorectal adenocarcinoma group 2-4: normal colorectalgroup

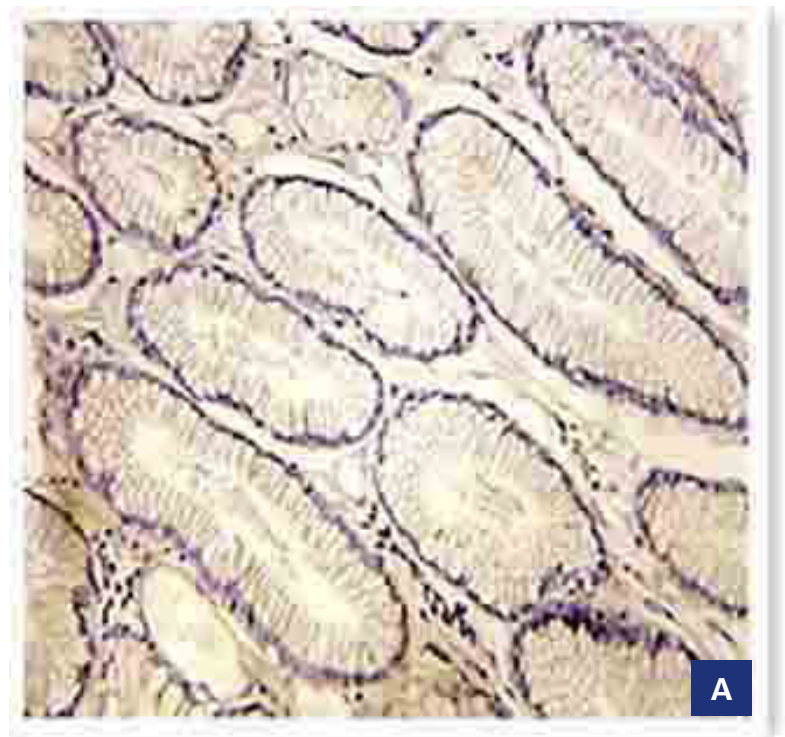

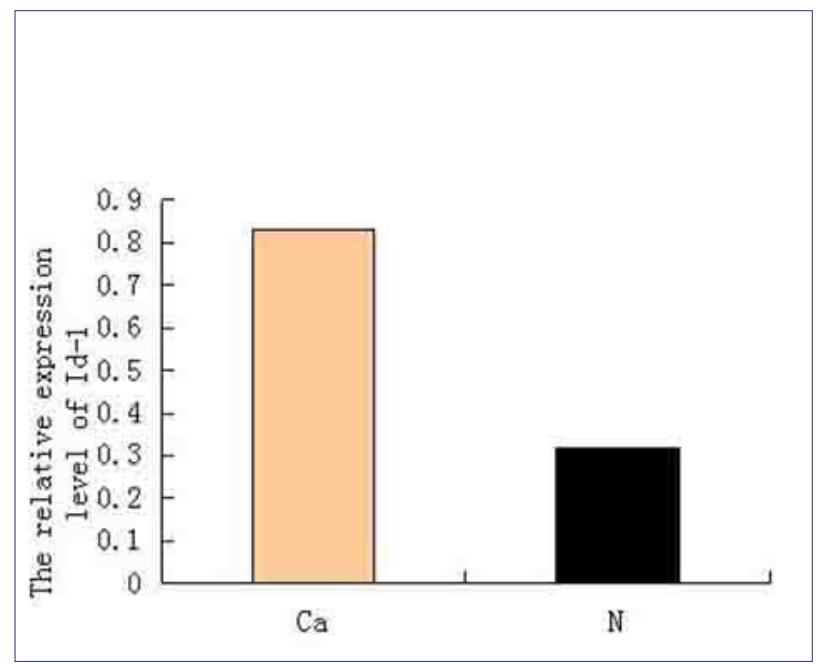

FIGURE 2. Expression level of Id-1 protein in colorectal adenocarcinoma and normal colorectal tissues detected by Western blot.

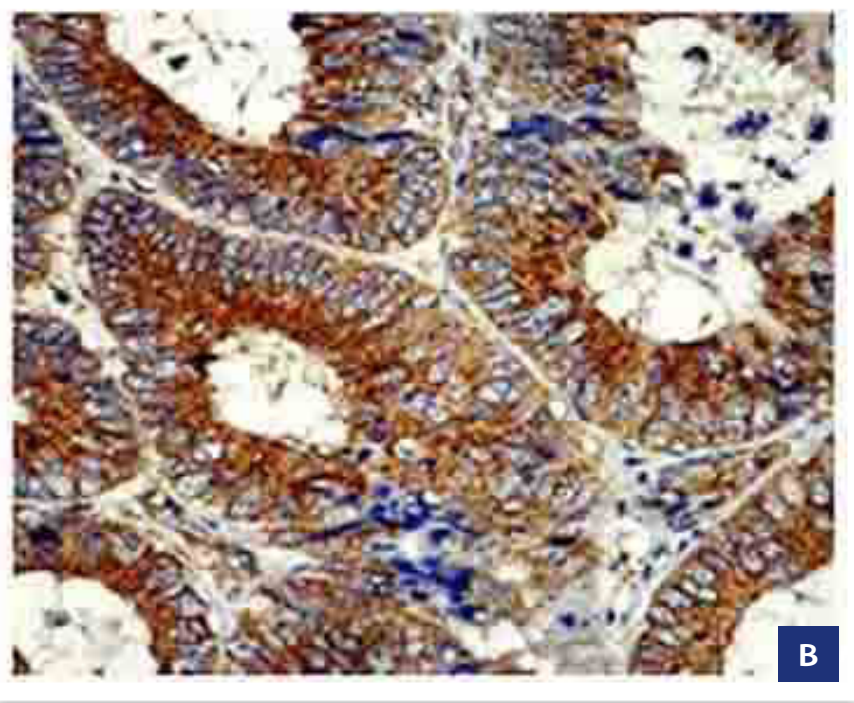

FIGURE 3. Expression level of Id-1 protein in colorectal tissues detected by Immunohistochemistry (SP×200).

A: Colorectal adenocarcinoma tissues B: Normal colorectal tissues 
mucous membrane and atypical hyperplastic gastric mucous membrane had a gradually increasing trend, and the difference was statistically significant. Furthermore, this was significantly correlated to tumor differentiation degree, infiltration depth, TNM stages, lymphatic metastasis, and prognosis. The lifetime of Id-1 positive patients was significantly shorter than that of negative ones. In-depth studies have found that Id-1 protein expression in patients with colorectal cancer accompanied by serosa infiltration significantly increased when compared with non-infiltration. The higher the TNM stage was, the higher the Id-1 protein expression became. This shows that the protein expression level of Id-1 was closely correlated to the malignant biological behavior of colorectal tumors, which plays an accelerated role in the invasion and metastasis of colorectal cancer. ${ }^{14}$ Immunohistochemical assays were performed on 62 cases of colorectal cancer tissues and found that Id-1 had 100\% positive staining in cancerous tissues. This was closely related to tumor infiltration depth and lymphatic metastasis and was positively correlated to Ki-67 and VEGF, considering that Id-1, Ki67, and VEGF had a synergistic effect. Furthermore, the study of Hu et al. ${ }^{15}$ revealed that Id-1 in colorectal cancer could upregulate the expression level of MT1MMP, inducing gene metal enzymes such as MMP-2 and MMP-9 to be overexpressed, thus enhancing the degradation of the basilar membrane and accelerating the infiltration and metastasis of cancer cells. In addition, studies have confirmed that Id- 1 could also induce the formation of tumor angiogenesis and provide a nutrition basis for the growth, infiltration, and metastasis of tumors through the two aspects of the combined action of promoting VEGF expression and inhibiting TSP-1 expression ${ }^{10}$.

In conclusion, the high expression of Id-1 is highly correlated to the occurrence, development, and malignant biological behavior of colorectal cancer. As a result, Id-1 is expected to become a new tumor monitoring index, providing an important reference for clinical treatment and prognosis monitoring. This experiment has only studied the expression of Id-1 in colorectal cancer and its relationship with clinicopathological features. However, the corresponding carcinogenic mechanism and role access were not studied. Furthermore, no related experiments have confirmed whether the application of Id-1 inhibitors can inhibit cell proliferation. This would be the future study direction for this subject.

List of abbreviations

- Inhibitors of DNA binding-1 Id-1

- hematoxylin and eosin H\&E

- helix-loop-helix HLH

- membrane type-1 matrix metalloproteinase MT1-MMP

- sodium dodecyl sulfate polyacrylamide gel electrophoresis SDS-PAGE

- reverse transcription-polymerase chain reaction RT-PCR

- Tumor Node Metastasis TNM

\section{Declaration}

Ethics approval and consent to participate:

This study was conducted in accordance with the declaration of Helsinki.

\section{Consent for publication}

We agree that the article is published.

\section{Availability of data and material}

Not applicable.

\section{Conflicts of interest statement:}

We declare that we do not have any commercial or associative interest that represents a conflict of interest in connection with the work submitted.

\section{Funding}

This study was supported by the 2015 planning project of medical scientific research of HeBei (20150058) and by the 2015 support project of Science and technology (152777237).

\section{Authors' contributions}

Xue-Liang Wu carried out the molecular genetic studies, participated in the sequence alignment and drafted the manuscript. Li-Kun Wang and Rui- Min Yang carried out the immunoassays. Bo-Liu participated in the sequence alignment. Jun Xue and FeiGuo participated in the design of the study and performed the statistical analysis. Dong-Dong Yang and Ming Qu conceived of the study, and Jun Xue participated in its design and coordination and helped to draft the manuscript. All authors read and approved the final manuscript 


\section{RESUMO}

OBJETIVO: O objetivo deste estudo é investigar a expressão de ld-1 em tecidos de adenocarcinoma colorretal em humanos e investigar sua correlação com os parâmetros patológicos clínicos de câncer colorretal.

MÉTODOS: Os níveis de expressão de proteína e mRNA Id-1 em 50 amostras de tecido colorretal normal e 50 amostras de tecido de adenocarcinoma colorretal foram detectados através de reação em cadeia de polimerase precedida de transcrição reversa e western blot. Além disso, a proteína Id-1 foi detectada através de imuno-histoquímica. A correlação entre a expressão de ld-1 e características clínico-patológicas foi analisada.

RESULTADOS: O nivel de expressão de mRNA Id-1 em tecidos de adenocarcinoma colorretal e tecidos colorretais normais foi de 0,96 \pm 0,03 versus $0,20 \pm 0,04$, respectivamente; a diferença foi estatisticamente significativa $(P=0,011)$. Além disso, a expressão da proteína Id-1 foi maior em tecidos de adenocarcinoma colorretal do que em tecidos colorretais normais $(0,82 \pm 0,04$ versus $0,31 \pm 0,02, P=$ $0,020)$. Além disso, a taxa de expressão positiva de proteínas Id-1 foi maior em tecidos de adenocarcinoma colorretal do que em tecidos colorretais normais (72,00\% vs. 24,00\%, X2=23,431, $p=0,000)$. A expressão de Id-1 foi correlacionada com a profundidade da invasão tumoral, estágio TNM, metástases linfonodais, invasão vascular e metástase hepática $(P<0,01)$. Todavia, essa expressão não se correlacionou com o tamanho do tumor e graus de diferenciação $(P>0,05)$.

CONCLUSÃO: A alta expressão de ld-1 em tecidos de adenocarcinoma colorretal desempenham um importante papel no processo do câncer, e é esperado que se torne um novo indicador de monitoramento de tumores para o diagnóstico clínico, tratamento e estimativa de prognóstico.

PALAVRAS-CHAVE: Neoplasias Colorretais. Imuno-histoquímica. Blotting, Western. Adenocarcinoma.

\section{REFERENCES}

1. Yang G, Zhang Y, Xiong |, Wu J, Yang C, Huang H, et al. Downregulation of Id1 by small interfering RNA in gastric cancer inhibits cell growth via the Akt pathway. Mol Med Rep. 2012;5(4):1075-9.

2. Bhattacharya R, Kowalski J, Larson AR, Brock M, Alani RM. Id1 promotes tumor cell migration in nonsmall cell lung cancers. J Oncol. 2010;2010:856105

3. Chen Z, Liu S, Sumida T, Sun S, Wei Y, Liu M, et al. Silencing Id-1 with RNA interference inhibits adenoid cystic carcinoma in mice. J Surg Res. 2011;169(1):57-66.

4. Ma LJ, He JC, Cai ZJ. Expression of inhibitor of differentiation -1 in cervical cancer tissues and its correlation with Ki-67. Chinese J Clin Pharmacol. 2015;31:627-30

5. Li JF, Hu YH, Dong YL. Expression and significance of differentiation inhibitor 1,3 and matrix metalloproteinase-9 in brain metastatic tumors. Chinese J Exp Surg. 2013;30:300-2.

6. Rothschild SI, Kappeler A, Ratschiller D, Betticher DC, Tschan MP, Gugger $M$, et al. The stem cell gene "inhibitor of differentiation 1" (IDI) is frequently expressed in non-small cell lung cancer. Lung Cancer. 2011;71(3):306-11.

7. Sun R, Chen W, Zhao X, LiT, Song Q. Acheron regulates vascular endothelial proliferation and angiogenesis together with Id1 during wound healing. Cell Biochem Funct. 2011;29(8):636-40.
8. Schmidt M, Asirvatham AJ, Chaudhary J. Inhibitor of differentiation 1 (IDI) promotes cell survival and proliferation of prostate epithelial cells. Cell Mol Biol Lett. 2010;15(2):272-95

9. Li W, Zhang CH, Hong YL, Li J, Hu YM, Zhao CF. Inhibitor of DNA-bingding-1/inhibitor of differentiation-I (ID-1) is implicated in various aspects of gastric cancer cell biology. Mol Biol Rep. 2012;39(3):3009-15.

10. Sharma P, Patel D, Chaudhary J. Idl and Id3 expression is associated with increasing grade of prostate cancer: Id3 preferentially regulates CDKNIB. Cancer Med. 2012;1(2):187-97

11. Pillai S, Rizwani W, Li X, Rawal B, Nair S, Schell MJ, et al. ID1 facilitates the growth and metastasis of non-small cell lung cancer in response to nicotinic acetylcholine receptor and epidermal growth factor receptor signaling. Mol Cell Biol. 2011;31(14):3052-67.

12. Li XM, Pang Y, Hou G. Expression and significance of Id-1 and HIF-1in esophageal carcinoma. Chinese J Clin. (Electronic Edition) 2013;7:1035-8.

13. Zhu B, Song C, Wang P. ID-I expression and clinical significance of ID1 in gastric cancer. J Shanghai Jiaotong University. 2013;33:298-302.

14. Guo Y. Expression and clinical significance of ID1 in gastric cancer. Chinese I Gen Surg. 2012;21:81-4

15. Hu B, Chen ZH, Chen ZK, Wu SB, Ge J, Yuan WJ. Expression and correlation of Id-1 and MMP-9 in human colorectal carcinoma. China | Mod Med. 2010;20:2630-3. 